\title{
Being adolescent with chronic renal failure: a view through existential phenomenology ${ }^{a}$
}

\author{
Ser adolescente com insuficiência renal crônica: um olhar por meio da fenomenologia existencial
} Ser adolescente con insuficiencia renal crónica: una ojeada por medio de la fenomenología existencial

Marcela Astolphi de Souza ${ }^{1}$ (i) Luciana de Lione Melo ${ }^{1}$

1. Universidade Estadual de Campinas. Campinas, SP, Brasil.
Corresponding author:

Marcela Astolphi de Souza.

E-mail: marcela.astolphi@gmail.com

Submitted on $12 / 02 / 2017$.

Accepted on $03 / 07 / 2018$.

DOI: 10.1590/2177-9465-EAN-2017-0368

\section{Abstract}

Objective: To understand adolescent's experiences with chronic renal failure disease, attended in a pubic teaching hospital at São Paulo state. Method: Phenomenological study, based on the philosophical reference of Martin Heidegger, with six adolescents interviewed by the following question: "What is it like to be an adolescent with chronic renal failure?" Results: Three ontological categories emerged: feeling different; experiencing renal insufficiency through renal replacement therapy; seeking normality. Conclusion: It was evidenced that the experiences of these adolescents were demonstrated by their behaviors of acceptance and denial, both related to chronic renal failure as a peculiar condition of their lives. Implications for practice: It is crucial that nursing directs a more careful look at adolescents with chronic renal failure, going beyond the disease and also considering the particularities of the adolescents necessary to face the adversities that arise from this experience.

Keywords: Adolescent; Chronic Renal Failure; Palliative Care; Pediatric Nursing; Qualitative Research.

\section{Resumo}

Objetivo: Compreender as vivências de adolescentes com insuficiência renal crônica atendidos em um hospital público de ensino, no interior do Estado de São Paulo. Método: Estudo fenomenológico, fundamentado no referencial filosófico de Martin Heidegger, com seis adolescentes entrevistados pela seguinte questão: "Como é ser adolescente com insuficiência renal crônica?" Resultados: Três categorias ontológicas emergiram: sentindo-se diferente; vivenciando a insuficiência renal por meio da terapia renal substitutiva; buscando a normalidade. Conclusão: Evidenciou-se que as vivências destes adolescentes foram permeadas por comportamentos, tanto de aceitação, como de negação, ambos relacionados à insuficiência renal crônica como condição peculiar de suas vidas. Implicações para prática: Torna-se imprescindível que a enfermagem direcione um olhar mais cuidadoso aos adolescentes com insuficiência renal crônica, indo além da doença e considerando as particularidades dos adolescentes necessárias ao enfrentamento das adversidades advindas dessa experiência.

Palavras-chave: Adolescente; Insuficiência Renal Crônica; Cuidados Paliativos; Enfermagem Pediátrica; Pesquisa Qualitativa.

\section{Resumen}

Objetivo: Comprender las vivencias de adolescentes con insuficiencia renal crónica atendidos en un hospital-escuela público, en el interior del Estado de São Paulo. Método: Estudio fenomenológico, fundamentado en el referencial filosófico de Martin Heidegger, con seis adolescentes entrevistados por la pregunta: "¿Cómo es ser adolescente con insuficiencia renal crónica?" Principales resultados: Tres categorías ontológicas emergieron: sintiéndose diferente; vivenciando la insuficiencia renal por medio da terapia renal substituta; buscando la normalidad. Conclusión: Se evidenció que las vivencias de estos adolescentes fueron expresadas por comportamientos, tanto de aceptación, como de negación, ambos relacionados a la insuficiencia renal crónica como condición peculiar de sus vidas. Implicaciones para la práctica: Es imprescindible que la enfermería direccione especial atención a los adolescentes con insuficiencia renal crónica, además de la enfermedad, y considerando las particularidades de los individuos.

Palabras clave: Adolescente; Insuficiencia Renal Crónica; Enfermería Pediátrica; Investigación Cualitativa. 


\section{INTRODUCTION}

Currently, Brazil is experiencing an epidemiological transformation permeated by a significant increase in nontransmissible chronic diseases (NTCD) and the reduction of infectious and parasitic diseases. ${ }^{1}$ Chronic renal failure (CRF), considered a NTCD, has a high morbidity and mortality rate and estimates show an increasing rise in its incidence and prevalence, being considered an epidemic in Brazil and in the world. ${ }^{2}$

CRF does not only trigger imbalances in the body, but it can also lead to changes in the quality of life and associated emotional disorders, due to the inherent difficulties of living with the disease, being in adolescents considered a unique situation due to vulnerability in the process of human development. ${ }^{3,4}$

Health monitoring often triggers interruptions in daily activities, affecting social relationships, and can generate conflicts with peers, manifested by feelings of inferiority and a decrease in self-image. Consequently, there may be increased levels of stress, depression and feelings of hopelessness related to perceptions of one's own health. . $^{3,5}$

Living with the CRF modified the daily life of adolescents accompanied at a service in the Brazilian Northeast region. Adolescents undergoing hemodialysis and peritoneal dialysis emphasized the change in body image as a factor of suffering, shame and discrimination. Among the daily activities, it is highlighted that the absence to school was determinant because it interfered in the process of socialization. ${ }^{6}$

Considering the difficulties imposed by the disease and the treatment of CRF in adolescence and the possibility of no longer recognizing oneself as an adolescent due to experiences related to illness, some concerns emerged and guided the study, among them: what it is like to be a teenager with CRF? What is it like to be young with several restrictions and limitations that the CRF and its treatment impose? Thus, the objective of this study was to understand the experiences of adolescents with chronic renal failure.

Considering that the CRF is a global health problem, a deeper understanding of this theme through a phenomenological view may bring important elements to broaden the possibilities of discussing this chronic health condition, together with the complexity involved in the process of becoming an adolescent, making it essential in health care, teaching and research.

\section{METHOD}

This study focused on the experiences of adolescents with CRF. Thus, considering the nature of the object, the choice for qualitative research, especially that of a phenomenological approach, is of particular relevance for the understanding of the sense that individuals attribute to their experiences on a given phenomenon. ${ }^{7}$
The theoretical milestone of Martin Heidegger's existential phenomenology was adopted. For the philosopher, the integral existence is called being-in-the-world, which means that the individual and his/her experiences are a whole, located in time and space. ${ }^{8}$

Being-in-the-world ${ }^{b}$ determines the meeting with the things and men of this world, so to be-in-the-world is to be-in-the-worldwith-others. The others, for adolescents with CRF, are the people they encounter throughout life - family, friends, health staff, but also things - the environment, hospital supplies, medications, and procedures. ${ }^{9}$

The research scenario was a Pediatric Inpatient Unit (PIU) and a Hospital Care Unit for Renal Disease (HCURD) of a public teaching hospital in the interior of the State of São Paulo, Brazil. Participants were six adolescents with CRF, of both sexes, aged between 12 and 18 years.

The inclusion criterion was to be an adolescent diagnosed with CRF at the time of the study, aged between 12 and 18 years, regardless of gender, hospitalized and/or in outpatient care for CRF. Thus, they were approached in the bed and/or during the hemodialysis procedure. The adopted age group followed the Statute of the Child and the Adolescent (SCA). ${ }^{10}$ Adolescents diagnosed with CRF who had limitations that impeded their verbal expression were excluded.

Obeying the ethical principles, this study was approved by the Research Ethics Committee (REC), Opinion number 155.909. The adolescents were individually invited to participate in the research after the consent of the parents/guardians through the Informed Consent Term, and the free and informed consent and consent of the research participant, in this case, the adolescent, which contemplates Resolution 466/2012. ${ }^{11}$

The adolescents who agreed to participate exposed their experiences, based on the following guiding question: "What is it like to be a teenager with chronic renal failure?". The speeches were recorded on a digital recorder and transcribed in full. Interviews were terminated when the speeches reached theoretical saturation, that is, they showed consistency from a continuous process of discourse analysis, from the perspective of the researcher. ${ }^{12}$

Phenomenological interviews occurred from September 2013 to February 2014. Four interviews were conducted at the PIU and two interviews were conducted during the hemodialysis sessions at the HCURD, in the presence of only the principal investigator and the participant, with an average duration of 25 minutes. All participants agreed to participate in the study.

To ensure anonymity, the adolescents were identified with the names of the characters that were part of the Brazilian television series Os Normais ${ }^{\circledR 13}$ and the choice was made due to the desire of adolescents to feel the same as healthy adolescents, that is, "normal". 
In order to understand the essence of the phenomenon in the discourses of adolescents, we opted for the analysis of the structure of the phenomenon, which follows the following steps: readings and re-readings of the adolescents' speeches, without any intention of any interpretation, capturing the global meaning of the experiences; new reading, in an attentive way, selecting the significant units, that is, fundamental structures of the phenomenon; grouping of significant units into ontological categories. ${ }^{7}$

In order to analyze the discourse of adolescents, the following orientations ${ }^{7}$ were used: global reading of the whole content of the speech, in order to apprehend its global configuration; rereading, attentive, in order to identify meaningful statements (units of meanings); search for convergences (elements that are common to several discourses) and divergences (elements that are peculiar to only one speech or a few); from the convergences/ divergences, elaboration of thematic categories.

Next, a descriptive synthesis based on the philosophical frame of Martin Heidegger was carried out. ${ }^{8}$ Thus, it was possible to reach a vague and average understanding of the phenomenon of the study, also called by the philosopher, of comprehensive analysis.

\section{RESULTS}

From the listening of the discourses of the adolescents with CRF it was possible to apprehend some facets of what it is like to-be-adolescent-with-chronic-renal-failure and the meanings of their experiences were grouped in common themes around the guiding question emerging the following ontological categories: Feeling different; Experiencing chronic renal failure through renal replacement therapy; and Seeking normality, discussed in the light of the Heideggerian referential and national and international literature.

\section{Feeling different}

For the adolescent-with-chronic-renal-failure, regardless of the time of diagnosis, when they look at the facticity of being affected by a chronic disease, adolescents feel different.

\section{$[$...] it is very different from the other children that have the} normal life, that can go out, go for a walk with the family, go traveling. It's as if we were different from them. Like we had one thing they did not have. And it's different. [...] Because you cannot do the same things that other girls do and always have to be hospitalized [...] Going to school, is not always possible [...] (Vani, 16 years old)

The disease causes physical changes, and the others, explicitly or implicitly, expose the adolescents, emphasizing these changes, which causes feelings of sadness. This is what happens to Vani in the school environment, where they laugh at her condition.
[...]Sometimes other children make fun because her tiny face gets bloated, the hair falls... they think it's funny, they do not know what's happening, they do not ask, they start to mock, make fun and it's bad. (Vani, 16 years old)

In addition to school, the difference with healthy adolescents is also revealed through their lifestyles, which include limitations such as going to the hospital three to six times a week, not being able to drink water in the desired amount, not being able to travel due to the need to perform hemodialysis periodically.

[...] three times a week you have to wake up early to go to the hospital. And then we can't stay at home [...] (Rui, 12 years old)

For me, the biggest limitation is not being able to drink water [...] (Maristela, age 17)

Thus, the feeling of being different permeates the existence of adolescents with CRF. However, to live this "different life", one of the alternatives is renal replacement therapy, the focus of the next ontological category.

\section{Experiencing chronic renal failure through renal replacement therapy}

Adolescents, from the moment they are diagnosed with CRF, are faced with a new condition of being, going from a healthy condition to having to live with CRF.

The new lifestyle imposed by the disease includes, in addition to medical consultations, dietary and physical restrictions, renal replacement therapy, be it hemodialysis or peritoneal dialysis. In the discourses of adolescents, both therapies have their difficulties.

Doing hemodialysis is bad because it gets sore here in the neck [points to the Schilley catheter implanted in the left jugular]. Because look, it's all hurt inside. [Points back to where the Schilley catheter is implanted, in the left jugular] [...] Full of cut, that's bad. [...] it's bad because, it is, has to be done, every time has it has to be done ... how do you say? Surgery. (Rui, 12 years old)

In the past days, it was bad when I was on peritoneal dialysis, you know? Peritoneal, in the belly [...] (Aldo, 18 years)

The fact that they are afflicted by a chronic disease, which requires lifelong treatment, causes suffering to adolescents. The speeches reveal the dissatisfaction of dependence related to renal replacement therapy.

Bad [says with much emphasis] [...] That's bad and I do not like it. (Rui, 12 years old) 
[...]we get weak, limping body, that hemodialysis maltreats quite a lot. And it's bad, and I get home I get weak, limp, without strength, I sleep the whole afternoon, I wake up at night to eat and I just sleep again (Vani, 16 years old)

At the same time that renal replacement therapy is vital, it is also a prison.

\section{[...] have to undergo hemodialysis or dialysis. (Vani, 16 years old)}

Trapped by therapy, they seek to find more flexible alternatives, in order to keep a daily life as close to normal as possible.

$[. .$.$] when I was doing CAPD [...] I had to get stuck in the$
machine at night, so I could not leave, right? So I opted
for hemodialysis. (Aldo, 18 years old)

Other available therapy is renal transplantation, but the results are not always positive.

[...] Sometimes when you do a transplant, it does not work. (Vani, 16 years old)

Thus, launched in the world of the disease, the adolescents coexist with the IRC and its peculiarities. However, in order not to succumb to the disease, they seek a sense of belonging to a group, what we call, in this study, of normality and which will be presented in the next ontological category.

\section{Seeking Normality}

Although the chronicity of the disease determines a significant problem in the life of adolescents, to extrapolate this daily, they seek normality, sometimes denying the disease, sometimes facing CRF, but minimizing its consequences.

\section{Normal [says very shyly]. Easy. I do everything. (Marcelo, 12 years old)}

So it is, for me, I think it's normal. It's the same thing... I do not think anything different like that. (Maristela, 17 years old)

Normal. (Bernardo, 12 years old)

[...] I go out at night, straight, feeling good [...] Ah! I live normal, huh. I'm even getting my license now, driver's license, I play soccer, everything, I do everything. It's normal [...] I do everything, I play ball, I ride bike, now I'm driving my motorcycle. I lead my life normal. (Aldo, 18 years old)
The speeches describe the activities of a typical adolescent, belonging to a group, independent and open to the possibilities of the social world. They are attempts to normalize the disease situation, sometimes concealing what appears to himself, of its own condition.

To understand teens with CRF, it is necessary to go where they are, to know their own modes of being-in-the-world, and the ways they relate with others that they meet and to them present themselves.

Being-with is constitutive of being-there, an existential characteristic of the being-in-the-world, referring to the meaning of being together with something or someone, besides the sense of relating, getting involved and living together. ${ }^{14}$ Thus, beingadolescent-with-chronic-renal-failure reveals itself in a unique way, portraying that the disease prevents activities typical for the age, such as attending school and belonging to a social group, which may determine specific non-renal co-morbidities, including depression, changes in body image and sleep disorders. ${ }^{3}$

In this study, concerns related to body image permeated the speeches of adolescents, from the appearance that the treatment determines as the presence of facial edema, until the necessity of using catheters for renal replacement therapy, which are apparent.

The presence of localized or generalized edema was associated, by adolescents with CRF, to depression, anxiety, fatigue, and decreased mobility. ${ }^{15} \mathrm{Adolescents}$ with an indication of renal transplantation identified changes in self-image as stressors too, perceiving themselves as different from other adolescents, ${ }^{16}$ which corroborates with the results of this study.

In addition to the stigma created in relation to adolescents with CRF, other anxieties emerge throughout their lives and are related to the scars resulting from invasive procedures, surgeries and changes in daily activities because of treatment.

When they realize the changes and limitations that occur in their lives as a result of CRF, they reinforce that they feel uncomfortable about substitute renal therapies because they require a commitment and thus the need to wake up early to go to hemodialysis sessions, besides physical suffering and complications. The changes in the daily life of adolescents, previously described, corroborates with results of other studies performed with adolescents with chronic renal disease and technology-dependent. ${ }^{17-19}$

Hemodialysis is fundamental for the survival of patients with CRF, therefore, it becomes necessary for the maintenance of the well-being of these adolescents, despite the suffering that it triggers. This treatment is based on ambiguous feelings of love and hatred, since it is a fundamental therapy for survival, but that makes them prisoners, dependent of this technology. ${ }^{5}$

The discourses of adolescents reveal them in a world, subjected to situations not always chosen, but that, in the condition of having-to-be, that is to say, to be delivered to their own existence, it is up to each one to deal with this universe as 
it's possible. The factuality for the adolescents of this study is to have chronic renal failure, which according to Heidegger, is how a being can be understood along with the other entities that come to him within his own world and determines his occupations.

To be occupied, for Heidegger, ${ }^{8}$ is a characteristic of beingin-the-world. That is, the term 'to be occupied' can mean: to execute, to finish, to resolve an issue, to fear. The expression to be occupied with something is used in the present investigation as an ontological term, for the designation of the being of a possible being-in-the-world.

Adolescents are concerned with the treatment and care that the CRF implies in their lives and demonstrate that these occupations are part of their existence.

The being-in-the-world's occupation refers to throwing itself outward, that is, transcending the immediate situation, which is imbricated in temporality. For Heidegger, time is a pre-sense of the past, the present and the future. Existence is experienced in an oscillating flow, a varied intensity and speed and they alternate according to the singular way of being-there to experience situations. ${ }^{20}$

As being-in-the-world, the adolescent finds meaning for his/her being just by existing and every time finds possibilities of being or not in a certain way. By appropriating oneself, in the face of the possibilities of choice that he/she makes and also of the alternatives that the world offers him/her, in dealing with things, being-in-the-world is related under the mode of occupation, and being-in a world reveals modes-of-being of being-occupied. ${ }^{8}$

The being-in-the-world is engaged in carrying out activities that are assigned to him/her, he/she makes use of the instruments that are essential to him/her and then realizes his/her existence. Thus, being involved in the CRF factuality, adolescents show their unique ways of being-in-the-world-with-renal-chronic-failure, portraying that the disease prevents them from attending school due to the need for hospitalization, or verbalizing that the water restriction, by itself, is the problem or still affirming that to undergo to numerous surgeries is bad.

It should be noted that, behind these activities, there are other demands of care as or more relevant than those already mentioned above. The challenges in the school context emerge linked to the fact that adolescents do not attend school regularly and this makes them feel uncomfortable for being away from friends, since they need interaction with the same age group. Thus, the difficulty in the learning process triggers isolation and inferiority. ${ }^{18,19}$

The literature states that there is an improvement in the quality of life of adolescents with chronic diseases when they perceive that their friends are present, support them and maintains links regardless of the disease. To this end, the adequate support provided by the social network of adolescents' friends acts as an important support to minimize the suffering of these individuals. ${ }^{21}$

For the adolescent with CRF, the search for life quality involves overcoming and understanding the situation that encompasses renal disease, since this is a factuality in which the adolescent is inserted, a situation in which he/she has to deal with the new and the unknown.

Dialytic treatment, its complications and limitations, favors the emergence of hope and expectation regarding renal transplantation. This other treatment option is perceived by adolescents as a possibility to separate their lives from the need for renal replacement therapy, eliminating the discomforts characteristic of hemodialysis. ${ }^{17,22}$

However, in some situations, kidney transplantation is not successful and failure of the procedure generates feelings of dissatisfaction as well as uncertainties regarding waiting for a new donor, scheduling of the surgery and whether the graft will be rejected or not.

The factuality that the adolescent with CRF is launched is every moment and every relationship, along with the historicity of being-in-the-world. The adolescent is confronted with the things, that is, those who come to meet him/her, and also have to deal with them, asking questions about them, letting them get lost, or even appropriating what they need.

The historicity of the adolescent with CRF reflects in their lived, in their experiences. In this context, it is expressed the importance of establishing a rich dialogue, permeated by the particularities of the adolescent, between him/her and the nurse, in order to reveal to both that the latter is not only responsible for the suffering, but for the care, which involves the reception and listening to the adversities that the adolescent experiences.

Care, not in the sense of watching over, but for the philosopher, is all that the being-there is, the way he/she deals with a certain situation, for it is a possibility of existence. In this singularity, being-there can surrender their existence so that others take charge of their decisions, not obliging them to be responsible for their attitudes. ${ }^{8}$

The propriety and the impropriety of its existence are conditions of being human and are related to the modes-of-being of each being-in-the-world that is shared, in which I am not myself, I am "us". The being-there is singular at the moment when they assume as their own and appropriates their condition of being finite, interested in the 'how' the being-there assumes their life.

Corroborating with the findings of this study, the adolescent demonstrates that he/she appropriates his/her condition of being-patient and tries to modify the therapy, bringing benefit to himself/herself. It demonstrates understanding of one's self by apprehending something - substitutive renal therapy - in its possibility of being and, in carrying out this understanding, it puts it into action.

For this, it is necessary to favor this adolescent to become and adapt in a positive way to the new way of life, through a health care that favors his/her quality of life..$^{5}$ In the results of this study, it was revealed that when the adolescent assumes his/her beingsick, besides the changes imposed by the disease in his/her daily life, it is possible to appropriate his/her treatment for his/her own benefits and that will improve his/her quality of life. 
The occupations of adolescents, as mentioned above, cover issues related to the treatment and care that the CRF imply in their lives, demonstrating that these occupations are part of their lives, as for some adolescents, the nephropathic condition is considered normal, since they can do everything, including going out at night.

Therefore, the problem of CRF also emerges as something that does not entail great problems in their daily life. At times denying, at others facing the disease, adolescents experience ways of being-with CRF, demonstrating that the condition of being-sick is part of their existence.

The word "normal" was present in the speeches of adolescents, revealing ways of being-in-the-world when they are dependent on a treatment, not only involving use of medicines, but also dependence on technologies, which meets the results of other studies on chronic disease in childhood and adolescence and dependence on technology. ${ }^{23,24}$

In this study, adolescents appropriate ways-of-being that show how normal it is to live with CRF. When they see the differences they have in relation to others, they try to say that their condition is normal, as a way of asserting to themselves that their existence is typical.

A study with adolescents with chronic diseases states that this phase of development is marked by the acquisition of skills in social relations and the need for peer acceptance. Thus, when they perceive themselves as different, they seek strategies to live with the disease. ${ }^{25}$

Young people have associated the CRF issue with their own ontic condition, that is, how their lives actually occur, with the facticity of their being-in normal. From references already inserted in their world of life, they presented attempts to normalize the situation of the disease, hiding what appears to themselves, from their own condition. By trying to 'normalize' their conditions, they conceal what appears to them, which is the constituent of their existence.

Faced with the factual condition of being-there in the escape of oneself, the adolescent confirms what he/she is, his constitution of being-in-the-world-with-others-and-with-things and refers to that facticity of which he/she flees. This may be the recognition of something that bothers him/her and that he/she runs away from, interpreting it as something normal.

However, in some way, the sickness that makes explicit the condition of being-able, points to finitude, which is a deeply troublesome issue for all men. Adolescents with chronic diseases do not explain clearly the possibility of death, but this is a threat as the disease worsens, ${ }^{26}$ which corroborates with the findings of this study, since adolescents experience a double nuisance, the uncertainty of treatment of the CRF disease and the question of its own finitude.

Adolescents, at times, fear how they will be and how they will stay throughout the treatment. This concern, which points to the future, is based on the can-be character of their existence, since they cannot predict their future in the face of various intercurrences that disease and treatment impose.

In Heidegger's work, the author affirms that at every moment, the existence of each being is at stake, being able to be and not be front of certain situations, because to exist is to live the time constituting the own being, constantly threatened by the own finitude. Being and may-not-being are two intertwined aspects of the existence of being-there.

The discomfort with finitude is present in the world of adolescents with chronic diseases, even if they do not present an imminent risk to death. However, experiences related to the treatment and hospitalization, experiencing suffering and the pain itself make the adolescents experience remarkable situations. In this context, it is perceived that they avoid talking about the subject of death, which shows the difficulty in living with this possibility. ${ }^{27}$

The question of finitude may be concealed, and Heidegger calls it an escape, ${ }^{8}$ existing, I run away from my finite character because it is uncomfortable. For him, our being, which is the closest to our existence, is what we have the most difficulty to perceive and understand.

The adolescents return to some past experiences, recalling the beginning of the treatment, which was permeated by adaptations in function of this new condition of being, and at this moment emerges their past. The present is revealed through the suffering triggered by the disease and difficulties about a continuous treatment and the future manifests itself in the hope of the hospital discharge and the reduction of the physical suffering. However, past, present and future emerge, sometimes separately, sometimes merging and confusing themselves during discourses.

Thus, adolescents, by retaking some past experiences, reveal and demonstrate future possibilities by what the world imposes and not by what they have chosen. This means that a teenager who was born and raised in the context of frequent hospitalizations and treatments due to chronic illness has in his/ her speech ways of being that update this condition.

Therefore, since they are adolescents with CRF, they perform the task of existing according to the concrete possibilities of the world in which they are immersed, for it is a task that the being-there has to do.

\section{CONCLUSION AND IMPLICATIONS FOR PRACTICE}

The search for the understanding of being a teenager with CRF revealed the uniqueness of living with the factuality of being affected by a chronical disease. The existence of adolescents with CRF has been revealed and hidden in their factual existences, emerging ways-of-being and of dealing with $\mathrm{CRF}$, that is, they deny and refuse, but at the same time accept CRF as a peculiar condition of their lives. 
When they perceive that they are launched-in-a-world permeated by collectivism, they share experiences with other adolescents, health professionals, friends and family, they show their being-in-the-world condition, affirming their normality when existing in the world.

From the production of this knowledge, in the assistance, especially Nursing, it is affirmed that it is necessary to search for strategies such as reception, in addition to a dialogue permeated by the trust that favors the relationship with the youth and, thus, it may be possible that this be-there appears, for it shows itself only in their being.

It is important that the nurse is concerned not only with attenuating the signs and symptoms of CRF, but also understands that caring is being-with-others, favoring the adolescent to be participative in her/his care, maximizing the adolescent's potential, accepting the difficulties, so that the care minimizes the possible wear and tear that the disease and the treatment imply in their existence, always in order to promote a favorable clinical condition in the existential daily life of the same.

Since the complexity of this being-there of the adolescent with CRF, which presents himself in a quest for unique ways of integrating into the world, it is reinforced the need to (re)think what can be done and what way to improve the world-life of the adolescent with CRF that is permeated by their own fragilities and singularities, in which the adolescent has the possibility of being and also of might-not-being.

In addition, the relevance of this study is based on the fact that it contributes to the understanding of the individualities and future reflections regarding the nursing care provided to the adolescents with CRF, based on the ways of being-in-the-world of adolescents. The results may contribute to subsidize new assistance strategies that also include the perspectives of the adolescents themselves.

\section{Sponsoring}

To the development agency Fundação de Amparo à Pesquisa do Estado de São Paulo - FAPESP, for assistance in research, in the form of a master's degree scholarship, process number 2013/21148-3.

\section{REFERENCES}

1. Malta DC, Oliveira TP, Santos MAS, Andrade SSCA, Silva MMA. Avanços do plano de ações estratégicas para o enfrentamento das doenças crônicas não transmissíveis, no Brasil, 2011-2015. Epidemiol Serv Saúde [Internet]. 2016 Apr/Jun; [cited 2016 Jul 20]; 25(2):37390. Available from: http://www.scielo.br/pdf/ress/v25n2/2237-9622ress-25-02-00373.pdf

2. Pinho NA, Silva GV, Pierin AMG. Prevalence and factors associated with chronic kdney disease among hospitalized patients in a university hospital in the city of São Paulo, SP, Brazil. J Bras Nefrol [Internet]. 2015 Jan/Mar; [cited 2017 Oct 10]; 37(1):91-7. Available from: http://www. scielo.br/scielo.php?pid=S0101-28002015000100091\&script=sci_ arttext\&tlng=en
3. Kelly MM. Children and adolescents with chronic kidney disease: a population at risk for more than just kidney disease. Nephrol Nurs $J$ [Internet]. $2016 \mathrm{Jan} / \mathrm{Feb}$; [cited $2016 \mathrm{Jul}$ 20]; 43(1):67-70. Available from: https://www.ncbi.nlm.nih.gov/pubmed/27025152

4. Tong A, Wong G, McTaggart S, Henning P, Mackie F, Carroll RP, et al. Quality of life of young adults and adolescents with chronic kidney disease. J Pediatr [Internet]. 2013 Oct; [cited 2016 Mar 14]; 163(4):117985. Available from: https://doi.org/10.1016/j.jpeds.2013.04.066

5. Coutinho MPL, Costa FG. Depression and chronic renal failure: a sóciopsychological analysis. Psicol Soc [Internet]. 2015 May/Aug; [cited 2017 Oct 12]; 27(2):449-59. Available from: http://dx.doi.org/10.1590/180703102015v27n2p449

6. Pennafort VPS, Queiroz MVO, Jorge MSB. Children and adolescents with chronic kidney disease in an educational-therapeutic environment support for cultural nursing care. Rev Esc Enferm USP [Internet]. 2012 Oct; [cited 2016 Mar 14]; 46(5):1057-65. Available from: http://dx.doi. org/10.1590/S0080-62342012000500004

7. Martins J, Bicudo MAV. Pesquisa qualitativa em psicologia: fundamentos e recursos básicos. São Paulo (SP): Centauro; 2005.

8. Heidegger M. Ser e Tempo. Campinas (SP): Editora da Unicamp Petrópolis (RJ): Vozes; 2012.

9. Inwood M. Dicionário Heidegger. Rio de Janeiro (RJ): Jorge Zahar Editor 2002.

10. Ministério da Saúde (BR). Lei № 8069 , de 13 de julho de 1990. Dispõe sobre o Estatuto da Criança e do Adolescente e dá outras providências [Internet]. Brasília (DF): Ministério da Saúde; 1999 [cited 2017 Oct 5] Available from: http://www.planalto.gov.br/ccivil_03/leis/L8069.htm

11. Ministério da Saúde (BR). Conselho Nacional de Saúde. Resolução № 466 de 12 de dezembro de 2012. Diretrizes e normas regulamentadoras de pesquisas envolvendo seres humanos. Brasília (DF): Ministério da Saúde; 2012

12. Fontanella BJB, Luchesi BM, Saidel MGB, Ricas J, Turato ER, Melo DM Amostragem em pesquisas qualitativas: proposta de procedimentos para constatar saturação teórica. Cad Saúde Pública [Internet]. 2011 Jan/Feb; [cited 2017 Oct 12]; 27(2):389-94. Available from: http://dx.doi. org/10.1590/S0102-311X2011000200020

13. Young F, Machado A. Os melhores momentos de "Os Normais". Rio de Janeiro (RJ): Objetiva; 2002

14. Sebold LF, Kempfer SS, Girondi JBR, Prado ML. Gestação na adolescência com enfoque no casal: movimento existencial. Rev Esc Enferm USP [Internet]. 2016 Jun; [cited 2017 Oct 13]; 50(n.esp):38-45 Available from: $\mathrm{http}: / / \mathrm{dx}$.doi.org/10.1590/S0080-623420160000300006

15. Selewski DT, Massengill SF, Troost JP, Wickman L, Messer KL, Herrshoff E, et al. Gaining the Patient Reported Outcomes Measurement Information System (PROMIS) Perspective in Chronic Kidney Disease: a Midwest Pediatric Nephrology Consortium study. Pediatr Nephrol [Internet]. 2014 Dec; [cited 2016 Sep 22]; 29(12):2347-56. Available from: https://www.ncbi.nlm.nih.gov/pmc/articles/PMC4213233/

16. Gonçalves YN, Gomes AMA. The experience of liver transplants in children and teenagers: the strong fragile life. Rev FSA [Internet]. 2013 Jul/Sep; [cited 2017 Oct 15]; 10(3):175-98. Available from: http://dx.doi. org/10.12819/2013.10.3.11

17. Abreus IS, Kourrouski MFC, Santos DMSS, Bullinger M, Nascimento LC, Lima RAG, et al. Crianças e adolescentes em hemodiálise: atributos associados à qualidade de vida. Rev Esc Enferm USP [Internet].2014 Aug [cited 2017 Apr 12]; 48(4):601-9. Available from: http://www.scielo.br/scielo. php?pid=S0080-62342014000400602\&script=sci_arttext\&\%20tlng=pt

18. Abreu IS, Santos $C B$. Impact of chronic kidney disease on quality of life of children and adolescents: integrative review. Rev Eletrônica Enferm [Internet]. 2014 Oct/Dec [cited 2017 Apr 12]; 16(4):833-41. Available from: https://www.fen.ufg.br/revista/v16/n4/pdf/v16n4a16.pdf. DOI: 10.5216/ree.v16i4.22831

19. Cabral PFA, Oliveira BE, Anders JC, Souza AIJ, Rocha PK. Perception of the child and adolescent in relation to being dependent on technology: fundamental aspects for nursing care. Texto Contexto Enferm [Internet] 2013 Apr/Jun; [cited 2017 Apr 14]; 22(2):343-51. Available from: http:// www.scielo.br/pdf/tce/v22n2/v22n2a10.pdf 
20. Gomes KKA, Castro EHB. Compreendendo a vivência da criança com cáncer através da fenomenología. Ayvu Rev Psicol [Internet]. 2016; [cited 2017 Apr 25]; 2(2):94-121. Available from: http://www.ayvu.uff. br/index.php/AYVU/article/view/67

21. Silva MEA, Moura FM, Albuquerque TM, Reichert APS, Collet N. Rede de apoio social na doença crônica infantil: compreendendo a percepção da criança. Texto Contexto Enferm [Internet]. 2017 Apr; [cited 2017 Apr 14]; 26(1):e6980015. Available from: http://dx.doi. org/10.1590/0104-07072017006980015

22. Ramos IC, Braga VAB, Cavalcante LP, Oliveira FJG. Adolescentes em hemodiálise: repercussões do adoecimento e tratamento na saúde mental. Ciênc Cuid Saúde [Internet]. 2015 Oct/Dec; [cited 2017 Apr 14]; 14(4):1427-35. Available from: http://dx.doi.org/10.4025/ cienccuidsaude.v14i4.26892

23. Brum CN, Paula CC, Padoin SMM, Zuge SS. Experience of diagnosis disclosure for teenagers with HIV. Texto Contexto Enferm [Internet]. 2016 Dec; [cited 2017 Apr 14]; 25(4):e17610015. Available from: http:// dx.doi.org/10.1590/0104-07072016001760015
24. Santos GS, Tavares CMM, Ferreira RE, Pereira CSF. Rede social e virtual de apoio ao adolescente que convive com doença crônica uma revisão integrativa. Aquichan [Internet]. 2015; [cited 2017 Apr 25] 15(1):60-74. Available from: http://aquichan.unisabana.edu.co/index. php/aquichan/article/view/3852

25. Silva LLT, Vecchia BP, Braga PP. Adolescer em pessoas com doenças crônicas: uma análise compreensiva. Rev Baiana Enferm [Internet]. 2016 Apr/Jun; [cited 2017 Apr 20]; 30(2):1-9. Available from: http:// dx.doi.org/10.18471/rbe.v30i2.14281

26. Menossi MJ, Zorzo JCC, Lima RAG. A dialógica vida/morte no cuidado do adolescente com câncer. Rev Latino Am Enferm [Internet]. 2012 Jan/Feb; [cited 2017 Abr 25]; 20(1):126-34. Available from: http://www. scielo.br/pdf/rlae/v20n1/pt_17.pdf

27. Moura FM, Costa Junior AL, Silva MEA, Reichert APS, Collet N. Hospitalized child and teenager with chronic diseases: feelings about death. Invest Educ Enferm [Internet]. 2015 Sep/Dec; [cited 2017 Apr 25]; 33(3):565-72. Available from: http://www.scielo.org.co/pdf/iee/ v33n3/v33n3a21.pdf

\footnotetext{
${ }^{a}$ As part of the "Being adolescent with chronical renal failure: a view through existential phenomenology" Masters' degree thesis, defended by its first author, in the UNICAMP's Nursing School's postgraduate program, on July 2014, under its second author's supervision. Available at: http://bdtd.ibict.br/vufind/Record/ CAMP_355c69ee1716807e86ad8e57b1a9d4e4

${ }^{\mathrm{b}}$ Heidegger's hyphens do not invariably have the purpose of analyzing a word by its components. He uses them to unite distinct words into a single, inseparable
} thought. Being-in-the-world, then, means that there can not be a world unless one is in it. ${ }^{9}$ 